\title{
Mycobacterium paratuberculosis DNA in Crohn's disease tissue
}

\author{
J D Sanderson, M T Moss, M L V Tizard, J Hermon-Taylor
}

\begin{abstract}
Crohn's disease has long been suspected of having a mycobacterial cause. Mycobacterium paratuberculosis is a known cause of chronic enteritis in animals, including primates, but may be very difficult to detect by culture. IS900 is a multicopy genomic DNA insertion element highly specific for $M$ paratuberculosis. A polymerase chain reaction (PCR) based on the $5^{\prime}$ region of IS900 and capable of the specific detection of a single $M$ paratuberculosis genome was developed. This was applied to DNA extracts of full thickness samples of intestine removed at surgery from $\mathbf{4 0}$ patients with Crohn's disease, 23 patients with ulcerative colitis, and 40 control patients without inflammatory bowel disease. Stringent precautions were taken that excluded contamination artefact. $M$ paratuberculosis was identified in 26 of $40(65 \%)$ Crohn's disease, in 1 of $23(4 \cdot 3 \%)$ ulcerative colitis, and in 5 of $40(12.5 \%)$ control tissues. Positive samples from Crohn's disease were from both the small intestine and colon, those from control tissues were from the colon only. All PCR internal control reactions were negative. The presence of $M$ paratuberculosis in a small proportion of apparently normal colonic samples is consistent with a previously unsuspected alimentary prevalence in humans. The presence in two thirds of Crohn's disease tissues but in less than $5 \%$ of ulcerative colitis tissues is consistent with an aetiological role for $M$ paratuberculosis in Crohn's disease.
\end{abstract}

Crohn's disease has long been suspected of having a mycobacterial cause. ${ }^{12}$ Mycobacterium paratuberculosis is a known specific cause of chronic enteritis in farm and other animals, ${ }^{34}$ including primates. ${ }^{5}$ Although this organism has been cultured from a very few patients with Crohn's disease, ${ }^{6-10}$ its role in this condition has been difficult to define. This is because of its very slow and uncertain growth in vitro culture, even from some infected animals, ${ }^{12}$ and the difficulties of distinguishing it by conventional means from organisms of the $M$ avium group, which are widespread in the environment ${ }^{13}$ and normal inhabitants of the animal and human intestine. ${ }^{14}$

St George's Hospital

Medical School, London

J D Sanderson

M T Moss

M L V Tizard

J Hermon-Taylor

Correspondence to:

Mr J D Sanderson,

Department of Surgery, St

George's Hospital Medical

School, Cranmer Terrace,

London SW17 0RE

Accepted for publication

18 February 1992
Characteristics of the subjects in each group

\begin{tabular}{llll}
\hline & $\begin{array}{l}\text { Crohn's } \\
\text { disease }\end{array}$ & $\begin{array}{l}\text { Ulcerative } \\
\text { colitis }\end{array}$ & Controls \\
\hline Total no & 40 & 23 & 40 \\
Age (mean (range)) (years) & $38 \cdot 1$ & $45 \cdot 8$ & $67 \cdot 7$ \\
& $(16-79)$ & $(14-72)$ & $(35-92)$ \\
Male/female ratio & $17 / 23$ & $10 / 13$ & $16 / 24$ \\
Small bowel & 29 & 0 & 15 \\
Colon & 11 & 23 & 25 \\
\hline
\end{tabular}

IS900 is a multicopy DNA insertion element in $M$ paratuberculosis and is specific for this organism. ${ }^{715}{ }^{16}$ Polymerase chain reaction (PCR) amplification of IS 900 provides a highly specific and sensitive method for detecting $M$ paratuberculosis independent of in vitro culture. ${ }^{1718}$ Here we describe the application of these methods to DNA extracts of surgically resected human intestine.

\section{Methods}

PATIENTS AND SAMPLES

Full thickness samples of intestinal tissue, approximately $2 \mathrm{~cm},{ }^{2}$ were obtained in the operating room immediately after surgical resection from 40 patients with Crohn's disease, 23 patients with ulcerative colitis, and 40 control patients without inflammatory bowel disease (colon cancer (35), gastric ulcer (2), sigmoid diverticulitis (2), and small gut sarcoma (1)). Tissue samples were immediately placed in dry sterile $20 \mathrm{ml}$ containers and were capped, labelled, and stored in a sealed plastic bag at $-20^{\circ} \mathrm{C}$ until processed. The diagnoses of Crohn's disease and ulcerative colitis were made on the basis of established clinical, radiological, and histological criteria. The age, sex, and site of resected tissue for each group are shown in the Table. Only obviously diseased intestine was taken in the case of Crohn's disease or ulcerative colitis. Normal intestinal tissue was sampled from control patients except for the two patients with diverticulitis in whom the sample was taken from the inflamed sigmoid colon.

\section{ANIMAL SAMPLES}

Intestinal tissue from animals with Johne's disease (ruminant paratuberculosis), confirmed by culture and histology, was kindly provided by Dr W Donachie, Moredun Research Institute, Edinburgh, UK.

\section{TISSUE PROCESSING}

Tissue was thawed, washed three times in TEN buffer (50 $\mu \mathrm{M}$ Tris/HC1, $100 \mathrm{mM}$ EDTA, 150 $\mathrm{mM} \mathrm{NaCl}, \mathrm{pH} \mathrm{8.0)}$ and blotted repeatedly on clean filter paper paying particular attention to the mucosal surface to minimise inclusion of luminal contents. A weighed sample (1-2 g) was then chopped (Mcllwain Tissue Chopper, McIlwain Laboratory Engineering, Guildford, UK) in $0.6 \mathrm{~mm}$ slices and homogenised (UltraTurrax T25) for one minute in TEN buffer ( 5 $\mathrm{ml} / \mathrm{l} \mathrm{g}$ of tissue). Homogenates were divided into $500 \mu \mathrm{l}$ aliquots for DNA extraction. 


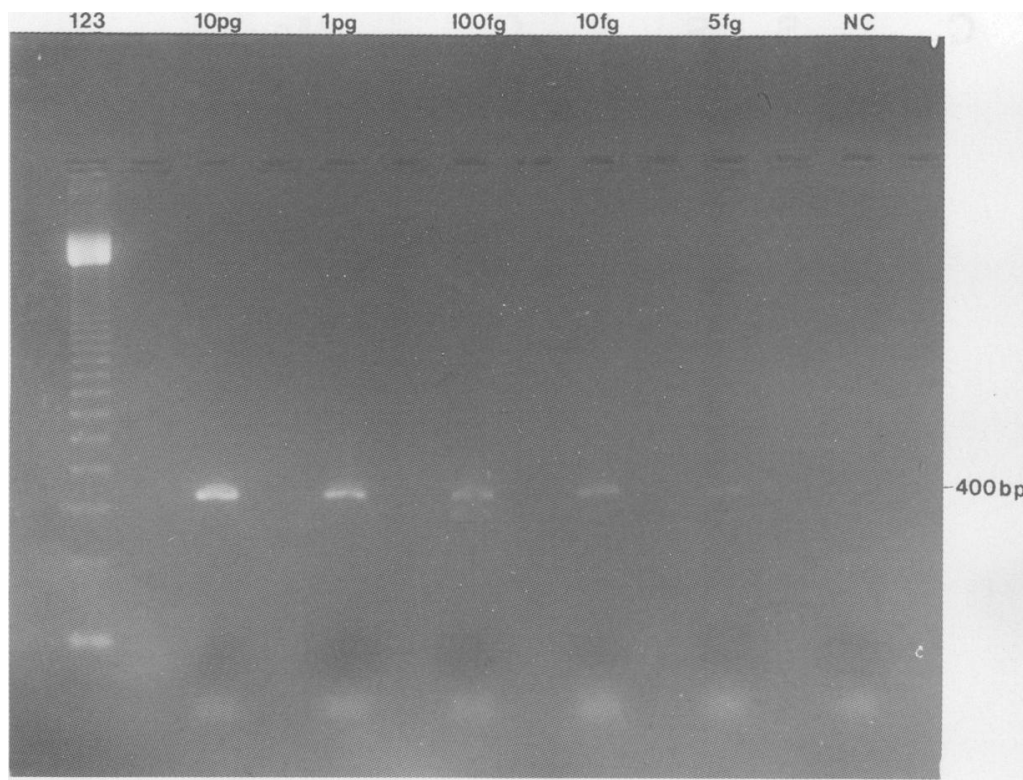

Figure 1: Detection of M paratuberculosis DNA by IS900 polymerase chain reaction $(P C R)$. One $\mu$ l aliquots of serial dilutions of genomic M paratuberculosis DNA extracted from a fohne's disease derived culture were submitted to 40 cycles PCR. Ten $\mu l$ of each product were run on a $2 \%$ agarose gel and stained with ethidium bromide $0.5 \mu \mathrm{g} / \mathrm{ml} 123 \mathrm{bp}$ ladder (Gibco-BRL). A 400 base pair (bp) amplification product is seen in each of the sample tracks. The PCR negative control (NC) containing no template has no amplification product. Five fg of $\mathrm{M}$ paratuberculosis DNA have been detected, equivalent to a single genome in the template material added to the PCR reaction mixture.

\section{DNA EXTRACTION}

Fifty $\mu$ l of chilled lysis buffer (1\% Triton X100, $10 \mathrm{mM}$ EDTA, $3 \mathrm{mM}$ dithiothreitol, $10 \mathrm{mM}$ Tris/ $\mathrm{HCl} \mathrm{pH} 7 \cdot 5$ ) were added to a $500 \mu \mathrm{l}$ aliquot of DNA extract, pipetted to disrupt the tissue, and centrifuged at $1500 \mathrm{~g}$ for five minutes to pellet large debris and a proportion of the eukaryotic nuclei. This step served to decrease proportionately the amount of human DNA in the final extract with a concomitant increase in sensitivity (data not shown). The supernatant was removed and submitted to DNA extraction with Subtilisin $10 \mathrm{mg} / \mathrm{ml}$ (Sigma) at $37^{\circ} \mathrm{C}$ for 12 hours, Lysozyme $50 \mathrm{mg} / \mathrm{ml}$ (Sigma) at $50^{\circ} \mathrm{C}$ for six hours, and Pronase $3 \mathrm{mg} / \mathrm{ml}$ (Sigma) $1 \%$ SDS at $37^{\circ} \mathrm{C}$ for 48 hours. After centrifugation at $12000 \mathrm{~g}$ for one minute to pellet cell debris, the supernatant was subjected to two cycles of phenol/chloroform extraction (equal volumes of phenol and chloroform/isoamyl alcohol mixture 24:1 saturated with TEN) and a single chloroform extraction. The DNA was then recovered by precipitation with $2 \mathrm{M}$ ammonium acetate and 2 volumes of $100 \%$ ethanol at $0^{\circ} \mathrm{C}$ for one hour, pelletted by centrifugation at $12000 \mathrm{~g}$ for 20 minutes, washed in $70 \%$ ethanol, bench dried, and resuspended in $500 \mu \mathrm{l}$ TEN buffer $(10 \mathrm{mM}$ Tris/HCl, $0 \cdot 1 \mathrm{mM}$ EDTA pH 8.8). A control buffer only tube was included with each run of homogenisation/DNA extraction.

PCR

Oligonucleotide PCR primers were selected to amplify a 400 base pair fragment (pcr400) of the $5^{\prime}$ portion of IS900 (nucleotides 22-421). The sequences of the primers were 5'GTTCGGGGCCGTCGCTTAGG-3' (Primer 90) and 5'-GAGGTCGATCGCCCACGTGA-3' (Primer 91), (synthesised by Oswell DNA service, Department of Chemistry, University of Edinburgh, UK). Reaction mixtures were made up containing the following reagents: PCR buffer (67 mM Tris/HCl, $16.6 \mathrm{mM}\left(\mathrm{NH}_{4}\right)_{2} \mathrm{SO}_{4}, 3.3 \mathrm{mM}$ $\mathrm{MgCl}_{2}$, bovine serum albumin (Gibco/BRL, UK)

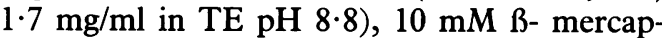
toethanol deoxynucleotide triphosphates (Pharmacia UK) $200 \mu \mathrm{M}$, primers $6 \mathrm{ng} / \mu \mathrm{l}$, Taq DNA polymerase (Amplitaq, Cetus) 5 units, and TE buffer $(10 \mathrm{mM}$ Tris $/ \mathrm{HCl}, 0 \cdot 1 \mathrm{mM}$ EDTA, $\mathrm{pH}$ $8 \cdot 8)$. Five $\mu \mathrm{l}$ of the final DNA extract were added to each PCR reaction premix totalling $50 \mu \mathrm{l}$. A total of 33 cycles PCR were performed (Techne Thermal Cycler, PHC-1, Cambridge UK) com-

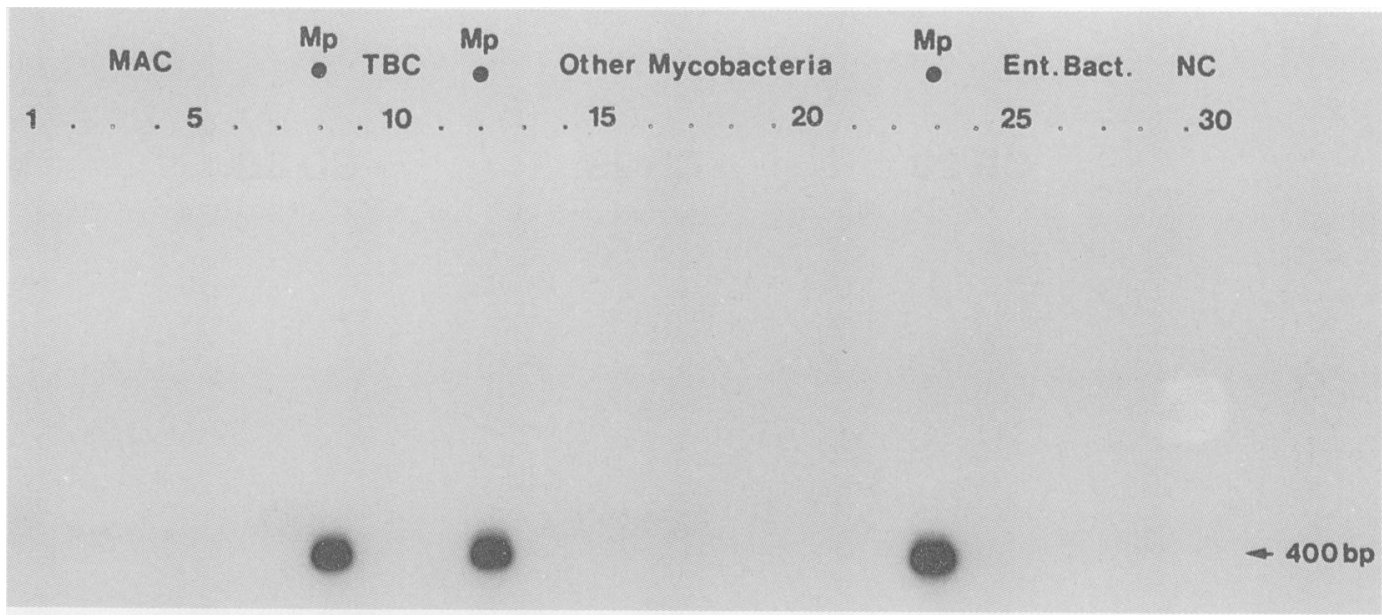

Figure 2: Autoradiograph showing IS900 polymerase chain reaction (PCR) applied to DNA extracted from 27 cultures of mycobacterial species and other bacteria. Amplification products run on $2 \%$ agarose gel after 33 cycles PCR and Southern blotted onto a nylon membrane; hybridised with ${ }^{32} P$-dCTP labelled pcr400 product, washed at high stringency, and exposed for four hours. $M A C-M$ avium complex, $T B C-M$ tuberculosis complex. A positive signal is seen only in the three $M$ paratuberculosis $(M p)$ lanes 8,12 , and 23. Other lanes are as follows: 1 and $2-M$ avium; 3 to $5-M$ avium $A I D S$ isolates servovars 9,1 and $6 ; 6-M$ scrofulaceum; $7-M$ avium subsp silvaticum (woodpigeon) ${ }^{21}: 22$ containing related insertion element IS $902^{23} ; 9-M$ tuberculosis; $10-M$ africanum; $11-M$ bovis; $13-M$ Kansasii; $14-M$ fortuitum; $15-$ $M$ xenopi; $16-M$ gordonae; $17-M$ malmoense; $18-M$ phlei; $19-M$ marinum; $20-M$ chelonei; $21-M$ smegmatis; 22 - M szulgai; 24 - Anaerobic peptococcus; 25 - Streptococcus faecalis; 26 - Escherichia coli; 27 - Streptomyces coelicolor containing related insertion element $I S 110^{24} ; 28-$ buffer only DNA extraction control; 29 and $30-P C R$ negative control $(N C)$. 
Figure 3: Autoradiograph showing detection of $M$ paratuberculosis DNA in tissue DNA extracts of intestinal tissue from a goat $(M)$ and $a$ sheep $(S)$ with Fohne's disease. Five $\mu$ l of a $10^{5}$ dilution of $M$ and $5 \mu \mathrm{l}$ of a $10^{7}$ dilution of $S$ were submitted to 33 cycles IS 900 polymerase chain reaction $(P C R)$ amplification, in triplicate, and each with one buffer only negative control (C). Ten $\mathrm{fg}$ of $\mathrm{M}$

paratuberculosis $D N A$

$(M p)$ were amplified as a positive control. PCR products were run on a $2 \%$ agarose gel, Southern blotted onto a nylon membrane, and hybridised at high stringency with ${ }^{32} \mathrm{P}$ labelled pcr400 product. The membrane was exposed to Kodak X-omat film for one hour

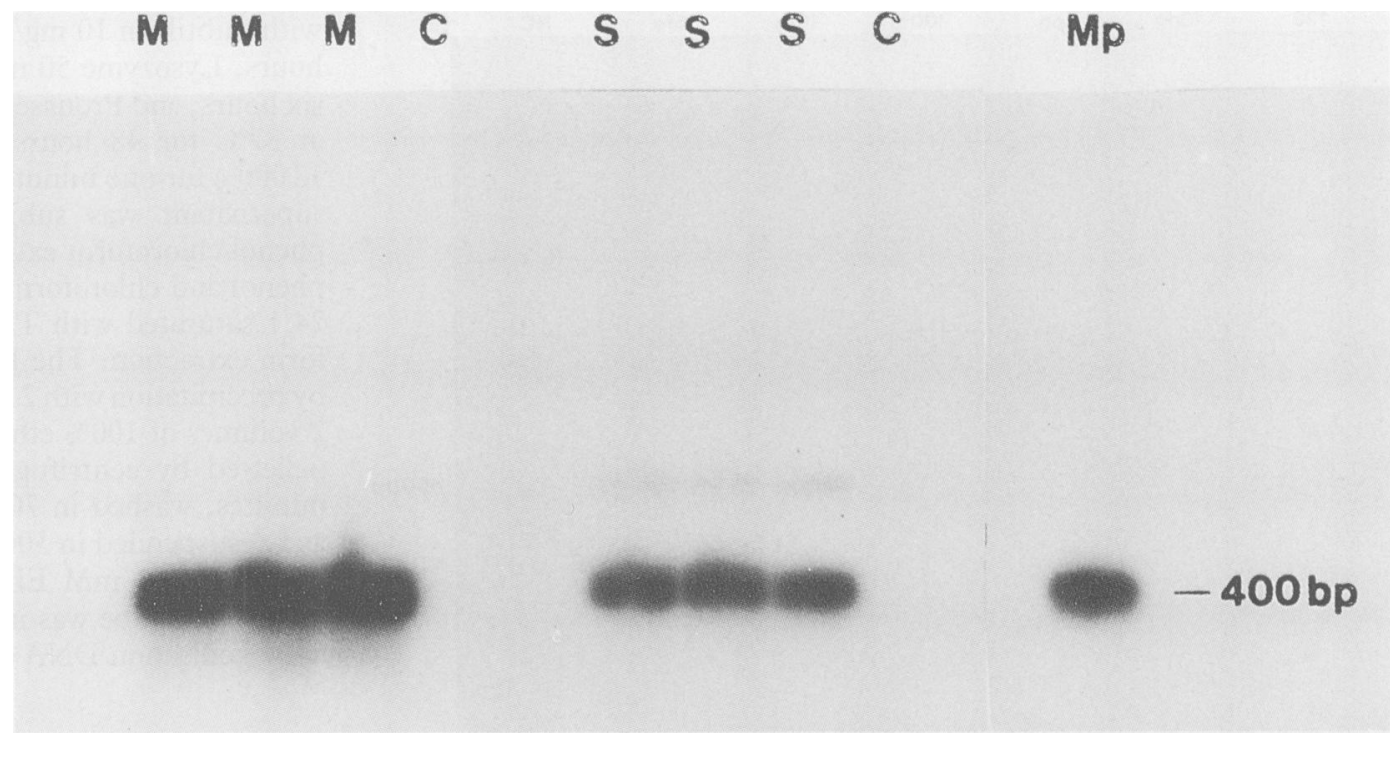

prising denaturation at $95^{\circ} \mathrm{C}$ for one minute, annealing at $58^{\circ} \mathrm{C}$ for one minute, and extension at $72^{\circ} \mathrm{C}$ for three minutes. Each tissue sample was run in triplicate with one buffer only PCR negative control. Each experiment included one positive control tube containing $10 \mathrm{fg}$ known $M$ paratuberculosis DNA.

\section{CONTAMINATION PRECAUTIONS}

Stringent precautions were taken throughout all tissue processing, DNA extraction and PCR steps to avoid false-positives because of laboratory contamination. These precautions included the use of widely separated contained laboratories for individual procedures, the use of dedicated or disposable equipment, ultraviolet irradiation of buffers and surfaces, capped PCR pre-mix tubes opened on a single occasion only for $5 \mu \mathrm{l}$ sample addition and the meticulous cleaning of surfaces, pipettes, and other apparatus with $1 \mathrm{M} \mathrm{HCl}, 10 \%$ hypochlorite, or $100 \%$

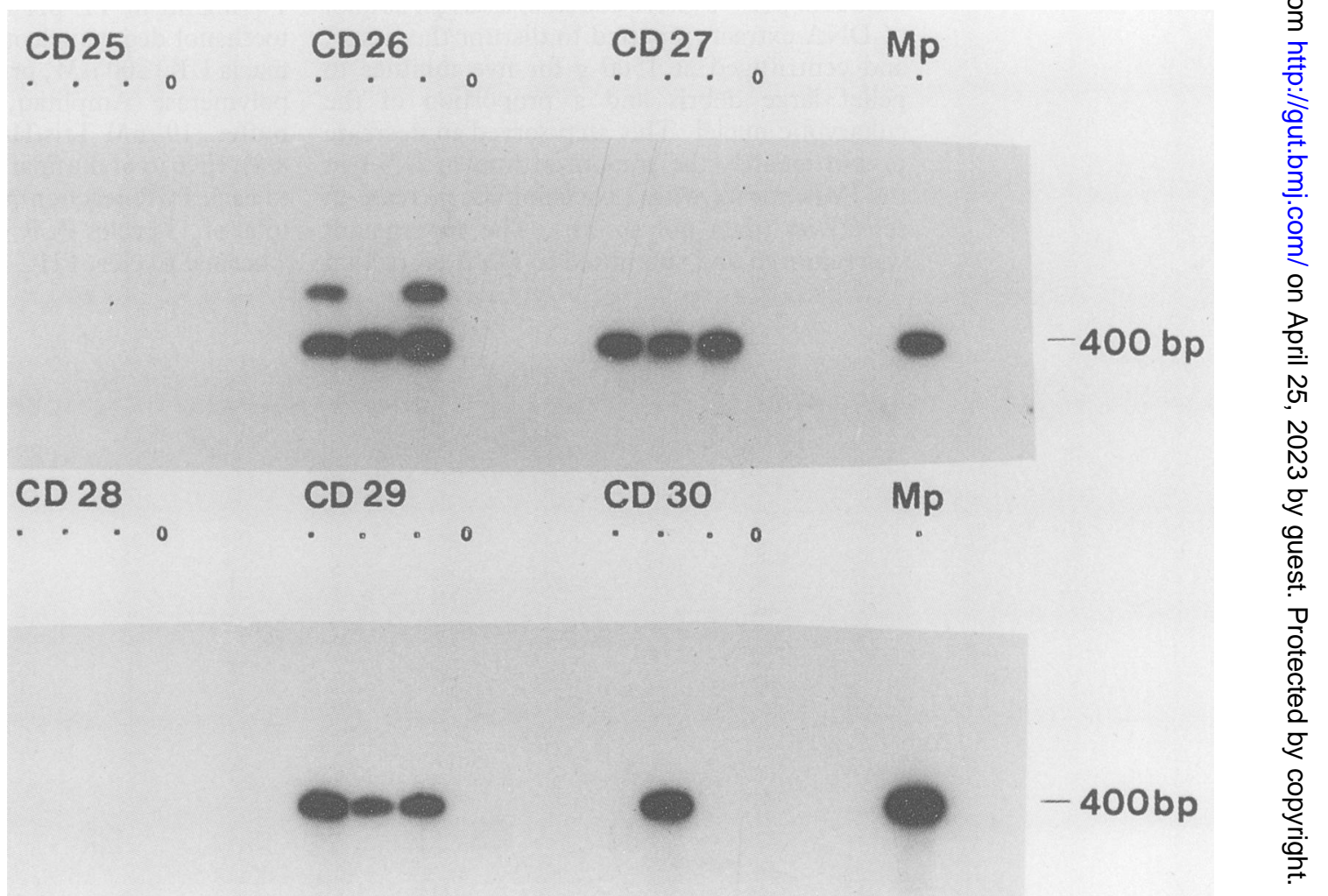

Figure 4: Autoradiographs showing detection of $\mathrm{M}$ paratuberculosis DNA in four of the six Crohn's disease tissue DNA extracts shown here. Samples were submitted to 33 cycles polymerase chain reaction $(P C R)$ amplification in triplicate, each with one buffer only PCR negative control sample (o). Ten $\mathrm{fg}$ of $\mathrm{M}$ paratuberculosis DNA were amplified as a positive control (Mp). PCR products were run on $2 \%$ agarose gel, Southern blotted onto a nylon membrane, and hybridised at high stringency with ${ }^{32} \mathrm{P}$ labelled pcr400 product. The membrane was exposed for 12 hours on Kodak X-omat film. CD26, CD27, and CD29 show triplicate positive signals. CD30 shows a single positive signal suggesting a lower abundance of $M$ paratuberculosis genomes. The additional higher molecular weight band in CD26 is seen with some M paratuberculosis isolates and may be PCR over-amplification. 
Figure 5: Autoradiographs showing detection of $M$ paratuberculosis DNA in one of the eight ulcerative colitis tissue DNA extracts shown here. Samples were submitted to 33 cycles polymerase chain reaction $(P C R)$ amplification in triplicate, each with one negative control (c). UC2 shows positive signals in two out of three sample lanes.

All other samples are negative. Ten fg M paratuberculosis DNA were amplified as positive control $(M p)$. Two

ulcerative colitis samples $\left(U C^{s}\right)$ have been spiked with $10 \mathrm{fg} \mathrm{M}$

paratuberculosis DNA to exclude inhibition in the assay. Both show positive signals equivalent to the 10 fg M paratuberculosis DNA alone.

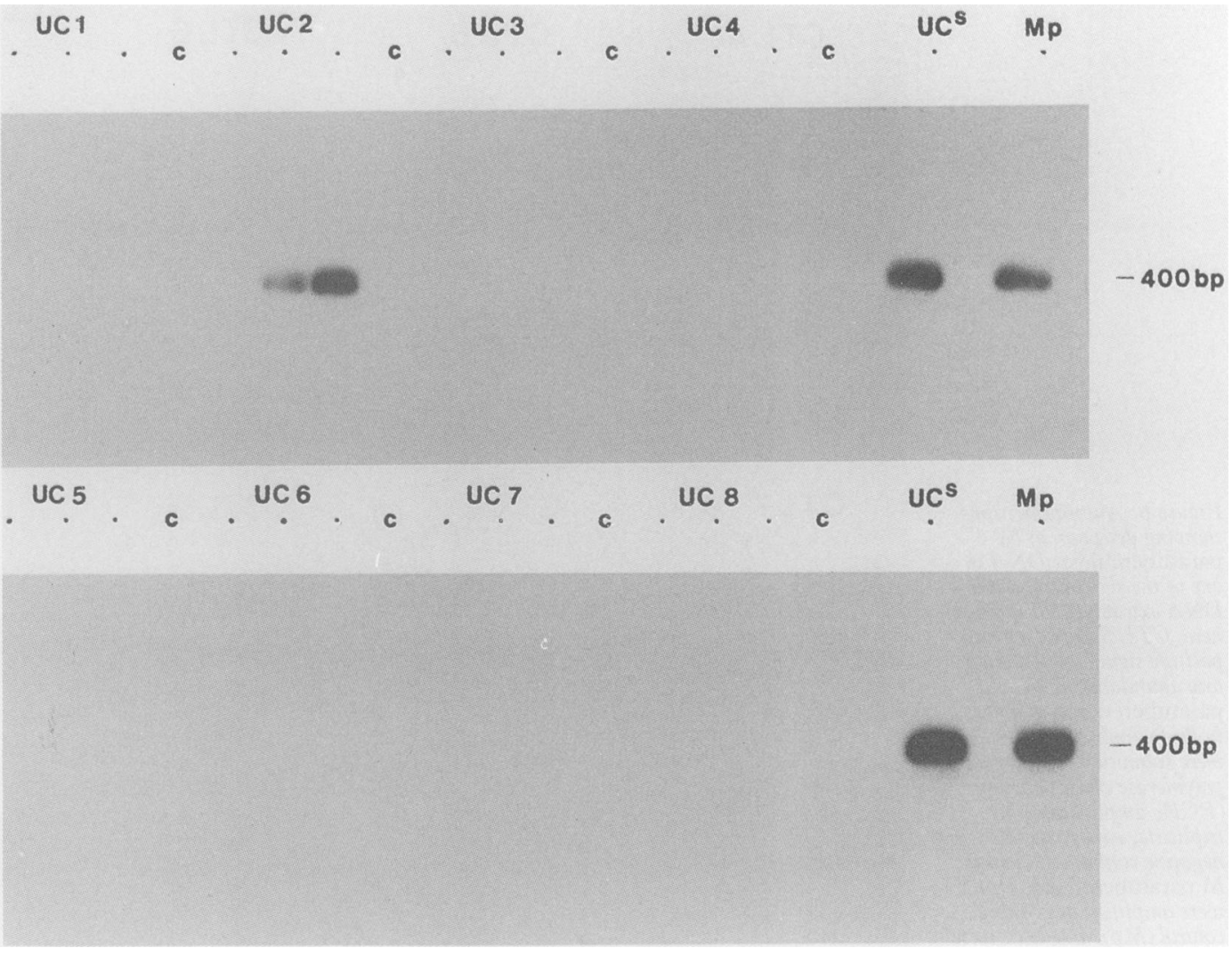

ethanol. These measures were monitored by the inclusion of TEN buffer blanks subjected to all steps in the tissue preparation and DNA extraction and the inclusion of a no template PCR control for each tissue sample.

\section{SOUTHERN BLOT HYBRIDISATION}

PCR products were run on $2 \%$ agarose gels (Sigma/Nu-sieve) and Southern blotted onto nylon membranes (Hybond-N, Amersham UK). Membranes were hybridised at $65^{\circ} \mathrm{C}$ overnight with the 400 base pair PCR product or a $228 \mathrm{bp}$ probe from within this fragment, labelled with ${ }^{32} \mathrm{P}$ dCTP (Multiprime DNA labelling kit, Amersham UK), in a buffer containing 3xSSC, $0 \cdot 1 \%$ bovine serum albumin (fraction V, Sigma), $0 \cdot 1 \%$ Ficoll (Pharmacia UK), 0.1\% polyvinylpyrrolidone (Sigma), $0.5 \%$ sodium dodecyl sulphate (SDS) (Sigma), 10\% dextran sulphate (Pharmacia UK), and $100 \mu \mathrm{g} / \mathrm{ml}$ sheared and denatured salmon sperm DNA (Sigma). The membranes were then washed at $65^{\circ} \mathrm{C}$ in $3 \times$ SSC $0 \cdot 1 \%$ SDS for $3 \times 30$ minutes, $1 \times$ SSC $0 \cdot 1 \%$ SDS for 30 minutes, and $0 \cdot 1 \times S S C$ and $0 \cdot 1 \%$ SDS for 30 minutes, and exposed on X-Omat film (Kodak) at $-70^{\circ} \mathrm{C}$ for 12 and 60 hours.

A positive result in the IS900 PCR test was indicated by the presence of the correct $400 \mathrm{bp}$ band in any one of the triplicate test lanes, or in any control lane.

\section{SENSITIVITY OF TISSUE DETECTION}

Five $\mu \mathrm{l}(1 \%)$ of the final tissue DNA extract were used in each of the triplicate $P C R$ reaction tubes, which together were equivalent to about $0.003 \mathrm{~g}$ of original tissue. Given the known PCR sensi- tivity (and assuming 100\% efficiency in the DNA extraction), the overall limit of detection was estimated to be about 300 bacilli per $1 \mathrm{~g}$ of tissue.

\section{STANDARD M PARATUBERCULOSIS DNA}

A goat Johne's disease derived $M$ paratuberculosis strain was kindly supplied by Dr Martin Woodward, Central Veterinary Laboratories, Weybridge, Surrey, UK. This was cultured on a mycobactin enriched Lowenstein-Jensen slope. The DNA was extracted enzymatically as above and the final concentration assessed by comparison with standard DNA solutions of known concentration on an ethidium bromide stained agarose gel and by optical density analysis at OD260.

\section{MYCOBACTERIAL DNA SAMPLES}

Broth and solid media cultures of different mycobacteria, enteric bacteria, and streptomyces (see legend to Fig 2) were used to demonstrate specificity of the IS900 PCR. Cell pellets from in vitro cultures were subjected to boiling for 20 minutes to release the microbial DNA, and $5 \mu \mathrm{l}$ aliquots of the resultant solution were used in PCR reactions. The availability of each bacterial DNA for the PCR IS900 test was confirmed by conserved region of the $16 \mathrm{~S}$ rRNA gene ${ }^{19}$ (data not shown).

\section{Results}

The IS900 PCR assay detected $5 \mathrm{fg}$ of the stock subsequent PCR using primers amplifying a 
Figure 6: Autoradiographs showing detection of $M$ paratuberculosis DNA in one of the six control tissue DNA extracts (CTL) shown here. CTL 5 shows a single positive signal suggesting $a$ low abundance of $M$ paratuberculosis genomes in this sample. Samples were submitted to 33 cycles polymerase chain reaction (PCR) amplification in triplicate, each with one negative control (o). Ten fg $M$ paratuberculosis $D N A$ were amplified as positive control $(M p)$. Products were Southern blotted and hybridised as for Figure 3.

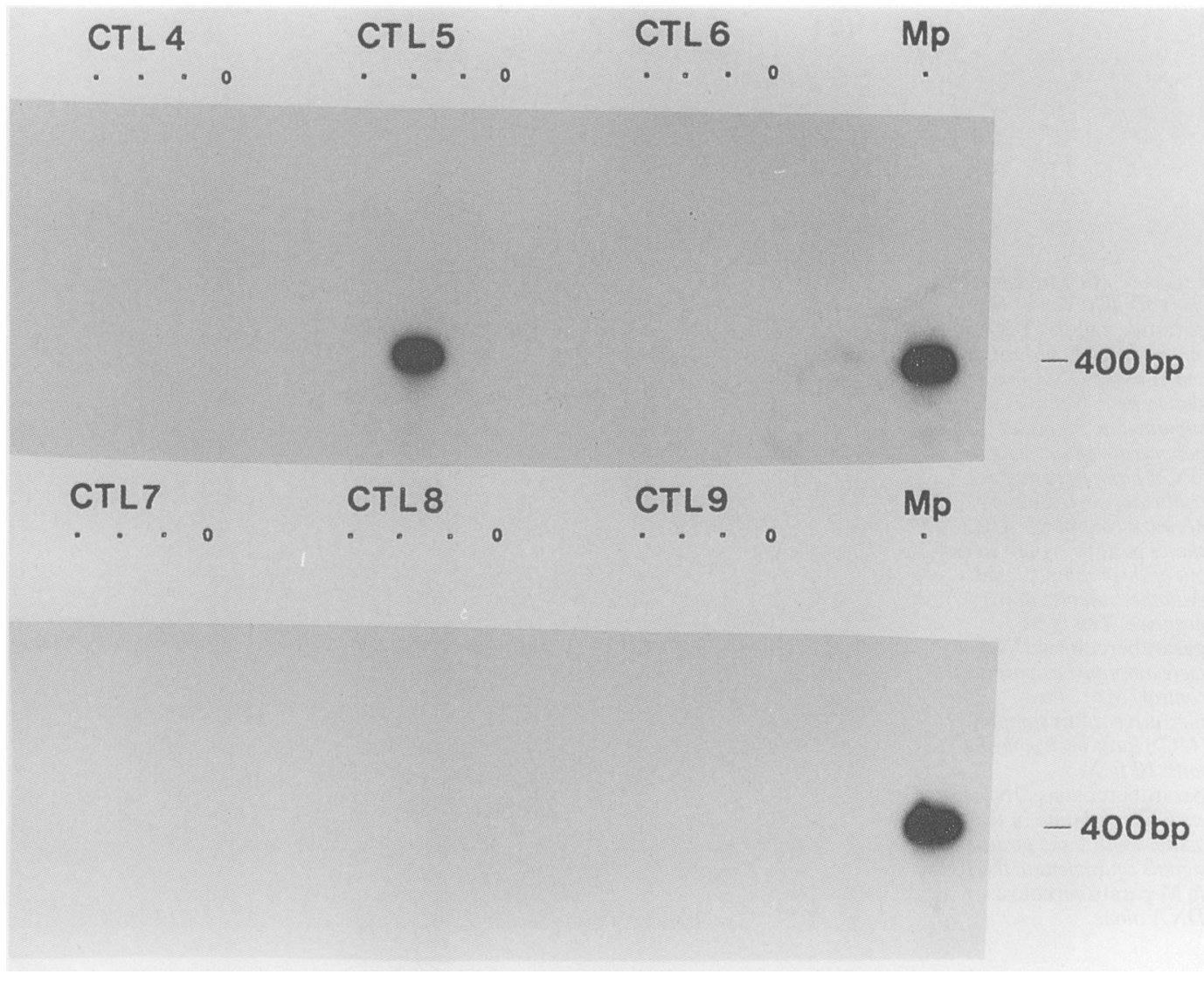

$M$ paratuberculosis DNA, equivalent to a single mycobacterial genome. After 40 cycles PCR this result could be visualised on an agarose gel stained with ethidium bromide (Fig 1).

As expected, all the known $M$ paratuberculosis isolates were IS900 PCR positive. IS900 PCR did not amplify a 400 bp product or show a hybridisation signal with any of the 24 other mycobacterial or enteric bacterial DNA extracts (Fig 2). The availability of bacterial DNA in each of these extracts was confirmed by a strongly positive PCR reaction using the $16 \mathrm{~S}$ rRNA primers. ${ }^{19}$

The correct $400 \mathrm{bp}$ amplification product was obtained in each case when the IS900 PCR was applied to the DNA extracted from goat and sheep Johne's disease intestinal tissues, following the procedure identical to that used for the human tissues (Fig 3). The native tissue DNA extracts had, however, to be diluted by a factor of $10^{5}$ for goat and $10^{7}$ for the sheep, to reduce the intensity of the IS900 PCR signal to approximate that obtained with the positive internal control reactions in the experiments.

Twenty six of the 40 (65\%) Crohn's disease intestinal tissues were positive for $M$ paratuberculosis (Fig 4); of these 19 were from the small intestine and seven from the colon. One of 23 (4.3\%) ulcerative colitis tissues (Fig 5) and 5 of the $40(12 \cdot 5 \%)$ control tissues were also positive (Fig 6). The five control samples that were positive were all from histologically normal colon in patients with colon cancer. Thirteen of the 26 positive Crohn's disease tissue samples were positive in two or all three lanes in the triplicate assay; the five positive control tissues were positive in one lane only. Both diverticulitis samples were negative. All of the 103 buffer only PCR control tubes and the 11 homogenisation/ DNA extraction blanks were negative. All of the known $M$ paratuberculosis positive internal controls, were positive.

In five of the positive Crohn's disease patients selected at random, we returned to the original stored tissue. The DNA extraction and IS900 PCR were repeated with simultaneous internal PCR controls as before. All the Crohn's disease samples were again positive and the PCR controls negative. Four PCR negative Crohn's disease, two ulcerative colitis, and two control tissue DNA extracts were spiked with $10 \mathrm{fg} M$ paratuberculosis DNA (equivalent to 2 mycobacterial genomes) and submitted to PCR to exclude inhibition in the assay. A positive signal was obtained in each case equivalent to that from 10 fg $M$ paratuberculosis DNA alone. PCR positive or negative results in the 40 Crohn's disease patients showed no relation with small or large gut involvement or the presence or absence of granulomata.

\section{Discussion}

The specificity for $M$ paratuberculosis of PCR assays based on their IS900 DNA insertion elements has been reported from work done in our own and other laboratories. ${ }^{1718}$ This is again demonstrated in the present study using the oligonucleotide primers and PCR assay conditions described. In addition, we show that the IS900 PCR reaction does not report the very closely related $M$ avium subsp silvaticum. ${ }^{20}$ This is the 'woodpigeon' strain of $M$ avium, also known to be a specific cause of chronic enteritis 
in cattle. ${ }^{2122} M$ avium subsp silvaticum contains 10 or 11 copies of IS $902,{ }^{23}$ a second member of this unusual family of mycobacterial DNA insertion elements with close structural homology to IS900 in M paratuberculosis.

Oligonucleotide primers previously described for the PCR detection of $M$ paratuberculosi ${ }^{17}$ were found not to be optimal for the human tissue DNA extracts. In the present study primer sequences were selected on the basis of minimal $3^{\prime}$ base mismatch, freedom from involvement in IS900 secondary structure, and specificity in relation to the known DNA sequences of other elements in this family. ${ }^{1523-26}$ Reaction conditions were optimised and maintained throughout the study, such that the IS900 PCR assay comfortably reported $10 \mathrm{fg}$ of target $M$ paratuberculosis DNA or less. This sensitivity, together with meticulous DNA extraction methods and other conditions described, were found to be important since if assay performance and sensitivity drifted, reproducible results were no longer assured. Insufficient overall sensitivity in the detection of $M$ paratuberculosis in a small number of fresh or fixed tissues probably accounts for the inability of some preliminary studies to detect this agent in Crohn's disease intestine ${ }^{2728}$; another study was positive. ${ }^{29}$

Throughout the present investigation, the results of IS900 PCR were clear cut. Either we saw a blank lane or the distinct $400 \mathrm{bp}$ band hybridising specifically with the specific ${ }^{32} \mathrm{P}-\mathrm{PCR}$ probe at high stringency (Figs 4 to 6). The number of positive lanes in each triplicate is a reflection of tissue microbial abundance. The extensive precautions adopted and the uniformly negative internal PCR control reactions strongly suggest that the positive results obtained in the PCR assays were not artefacts of laboratory contamination (well known in PCR systems, ${ }^{3031}$ ) but correctly indicated the presence of IS 900 containing $M$ paratuberculosis DNA in the corresponding tissue extracts.

The true distribution of the animal enteric pathogen $M$ paratuberculosis in the environment, in water supplies, and in human foods ${ }^{32}$ is largely unknown because of the need hitherto to rely on the uncertainties of isolation and conventional characterisation in in vitro culture. ${ }^{33} 34$ The finding of the DNA of this organism in a small proportion of samples of apparently normal colonic tissue including mucosa, is consistent with a previously unsuspected alimentary prevalence in humans. If the presence of $M$ paratuberculosis in the inflamed intestinal tissues of most patients with Crohn's disease in the present study was a consequence of opportunistic invasion due to pre-existing disease, we could reasonably expect to find a broadly similar situation in intestine affected by ulcerative colitis (or diverticulitis). The low proportion of positive results in this group $(4.3 \%)$ favours an aetiological association between $M$ paratuberculosis and the chronic enteritis of Crohn's disease in humans.

Although far short of proof, our findings are consistent with the possibility that a majority of Crohn's disease in southern England may be caused by $M$ paratuberculosis, in a tissue abundance one hundred thousand to 10 million times lower than that commonly occurring in corres- pondingly diseased animals. A tissue microbial abundance below the limit of detection by our present methods may account for some of the PCR negative results on Crohn's disease patients. An additional and equally probable explanation would be the involvement of one or two other members of a small group of environmental mycobacteria very closely related to $M$ paratuberculosis, and also specifically capable of causing chronic enteritis in an appropriately susceptible host. This would be entirely compatible with the known clinicopathological heterogeneity of Crohn's disease. Methods similar to those used in the present study will need to be applied to investigate these agents.

The immunological detection of $M$ paratuberculosis in humans has so far been inconsistent or negative. ${ }^{35-37}$ This may reflect the phenotype of this organism in the human host and the difficulties of differentiating specific responses to $M$ paratuberculosis from existing immunity to $M$ avium and other mycobacteria widespread in the environment and in ourselves. Epitope mapping and the availability of chemically defined sequences within the $\mathrm{p} 43$ protein encoded by IS 900 may offer a promising way forward in this field.

This work was supported by grants from the Ileostomy Association of Great Britain and Ireland, Action Research, and the Wellcome Trust, to whom we express our appreciation. We are grateful to many colleagues for contributing tissue samples.

This work was previously outlined in abstract form. Sanderson et al. Polymerase Chain Reaction (PCR) directly reports Mycobacterium paratuberculosis ( $M$ para) genomes in Crohn's disease tissue DNA extracts. Gastroenterology 1991; 100: A247.

1 Dalziel TK. Chronic interstitial enteritis. BMF 1913; ii: 1068-70.

2 Crohn BB, Ginzburg L, Oppenheimer GD. Regional ileitis, a pathologic and clinical entity. ₹AMA 1932; 99: 1323-9.

3 Johne HA, Frothingham L. Ein eigenthuemlicher Fall von Tuberkulose beim Rind. Dische Z Tiermedicin Pathol 1895 , 21: 438-54.

4 Chiodini RJ, van Kruiningen HJ, Merkal RS. Ruminan paratuberculosis (Johne's disease): the current status and future prospects. Cornell Vet 1984; 74: 218-62.

5 McClure HM, Chiodini RJ, Anderson DC, Swenson RB, Thayer WR, Coutu JA. Mycobacterium paratuberculosis (Johne's disease) in a colony of stump-tail macaques (Macaca arctoides). F Infect Dis 1987; 155: 1011-19.

6 Chiodini RJ, Van Kruiningen HJ, Merkal RS, Thayer WR, Coutu JA. Characteristics of an unclassified mycobacterium species isolated from patients with Crohn's disease. $\mathcal{F}$ Clin species isolated from patients

7 McFadden JJ, Butcher PD, Chiodini R, Hermon-Taylor J. Crohn's disease-isolated mycobacteria are identical to Mycobacterium paratuberculosis, as determined by DNA probes that distinguish between mycobacterial species. $f$ Clin Microbiol 1987; 25: 796-801.

8 Haagsma J, Mulder CJJ, Eger A, Bruins J, Ketel RJ, Tytgat GNJ. Mycobacterium species isolated from patients with Crohn's disease. In: MacDermott RP, ed. Inflammatory bowel disease: current status and future approach. Amsterdam Excerpta Medica, 1988: 535-7.

9 Coloe P, Wilks CR, Lightfoot D, Tosolini FA. Isolation of Mycobacterium paratuberculosis in Crohn's disease. Aust Microbiol 1986; 7: 188A.

10 Gitnick G, Collins J, Beaman B, Brooks D, Arthur M, Imaeda $T$, et al. Preliminary report on isolation of mycobacteria from T, et al. Preliminary report on isolation of mycobacteria from

11 Chiodini RJ. Crohn's disease and the Mycobacterioses: a review and comparison of two disease entities. Clin Microbio Rev 1989; 2: 90-117

12 Buergelt CD, Hall C, McEntee K, Duncan JR. Pathologica evaluation of paratuberculosis in naturally infected cattle. Vet Pathol 1978; 15: 196-207.

13 Kazda JF. The principles of the ecology of mycobacteria. In Ratledge C, Stanford J, eds. The biology of the mycobacteria. London: Academic Press, 1983: 323-41.

14 Portaels F, Larsson L, Smeets P. Isolation of Mycobacteri from healthy person's stools. Int $\mathcal{F}$ Leprosy 1988; 56: 468-71

15 Green EP, Tizard MLV, Moss MT, Thompson J, Winter bourne DJ, McFadden JJ, et al. Sequence and characteristics of IS 900 , an insertion element identified in human Crohn's disease isolate of Mycobacterium paratuberculosis. Nucleic Acids Res 1989; 17: 9063-73.

16 Hermon-Taylor J, Moss MT, Tizard MLV, Malik Z, Sanderson JD. Molecular biology of Crohn's disease mycobacteria Baillieres Clin Gastroenterol 1990; 4: 23-42. 
17 Moss MT, Green EP, Tizard MLV, Malik Z, Hermon-Taylo J. Specific detection of Mycobacterium paratuberculosis by DNA hybridisation with a fragment of the insertion elemen IS900. Gut 1991; 32: 395-8.

18 Vary PH, Anderson PR, Green E, Hermon-Taylor J, McFadden JJ. Use of highly specific DNA probes and the polymerase chain reaction to detect mycobacterium paratuberculosis in Johne's disease. F Clin Microbiol 1990 28: 933-7.

19 Boddinghaus B, Rogall T, Flohr T, Blocker H, Bottger EC Detection and identification of mycobacteria by amplificaDetection and identification of mycobacteria by
tion of rRNA. $\mathcal{F}$ Clin Microbiol 1990; 28: 1751-9.

20 Thorel M-F, Krichevsky M, Levy-Frebault VV. Numerical taxonomy of mycobactin-dependent mycobacteria, emended description of mycobacterium avium, and description of mycobacterium avium subsp avium subsp nov mycobacterium avium subsp paratuberculosis subsp nov, and mycobacterium avium subsp silvaticum subsp nov. Intern $\mathcal{F}$ Syst Bacteriol 1990; 40: 254-60.

21 Matthews PRJ, McDiarmid A. The production in bovine calves of a disease resembling paratuberculosis with Mycobacterium sp isolated from a woodpigeon (Columbia palumbus L). Vet Rec 1979; 104: 286

22 Collins, P. Matthews PRJ, McDiarmid A, Brown A. The pathogenicity of mycobacterium avium and related pathogenicity of mycobacterium avium and related 1983; 16: 27-35

23 Moss MT, Malik Z, Tizard MLV, Green EP, Sanderson JD Hermon-Taylor J. IS902, an insertion element of the chronic enteritis causing Mycobacterium avium subsp silvaticum. F Gen Microbiol 1992; 138: 139-45.

24 Bruton CJ, Chater KF. Nucleotide sequence of IS110, an insertion sequence of Streptomyces coelicolor A3(2). Nucleic Acids Res 1987; 15: 7053-65.

25 Leskiw BK, Mevarech M, Barritt LS, Jensen SE, Henderson DJ, Hopwood DA, et al. Discovery of an insertion sequence, IS116, from Streptomyces clavuligerus and its relatedness Dilo, fromess to other transposable elements
Microbiol 1990; 136: 1251-8.
26 Ashby MK, Berquist PL. Cloning and sequence of IS1000, a putative insertion sequence from thermus thermophilus HB8. Plasmid 1990; 24: 1-11.

27 Wu SWP, Pao CC, Chan J. Lack of mycobacterial DNA in Crohn's disease tissue. Lancet 1991; 337: 174-5.

28 Rosenberg WMC, Bell JI, Jewell DP. Mycobacterium paratuberculosis DNA cannot be detected in Crohn's disease tissues. Gastroenterology 1991; 100: A611.

29 Quirke P, Dockey D, Taylor GR, Lewis FA, Hawkey P, Graham D. Detection of Mycobacterium paratuberculosis in inflammatory bowel disease. Gut 1991; 32: A572

30 Eisenstein BI. The polymerase chain reaction. A new method of using molecular genetics for medical diagnosis. $N \mathrm{Englf}$ of using molecular gene

31 Erlich HA, Gelfand D, Sninsky JJ. Recent advances in the polymerase chain reaction. Science 1991; 252: 1643-51.

32 Taylor TK, Wilks CR, McQueen DS. Isolation of Mycobacterium paratuberculosis from the milk of a cow with Johne's disease. Vet Rec 1981; 9: 532-3.

33 Hermon-Taylor J. Mycobacterium paratuberculosis; environ mental mycobacteria and Crohn's disease. In: Peters TJ, ed. The cell biology of inflammation in the gastro-intestinal tract. Hull: Corners Publications, 1990: 323-42.

34 Sanderson JD, Hermon-Taylor J. Mycobacterial diseases of the gut: some impact from molecular biology. Gut 1992; 33: the gut:

35 Cho S-N, Brennan PJ, Yoshimura HH, Korelitz BI, Graham DY. Mycobacterial aetiology of Crohn's disease: serologic study using common mycobacterial antigens and a speciesspecific glycolipid antigen from Mycobacterium paratuberculosis. Gut 1986; 27: 1353-6.

36 Kobayashi K, Blaser MJ, Brown WR. Immunohistochemica examination for mycobacteria in intestinal tissues from patients with Crohn's disease. Gastroenterology 1989; 96: 1009-15.

37 Tanaka K, Wilks M, Coates PJ, Farthing MJG, Walker-Smith JA, Tabaqchali S. Mycobacterium paratuberculosis and Crohn's disease. Gut 1991; 32: 43-5. 